\title{
Anthropologists, Corporate Responsibility and Oil in Ecuador and Nigeria
}

\author{
Robert Wasserstrom \\ Terra Group \\ Susan M. Reider \\ Terra Group
}

State-owned national oil companies (NOCs) now control $90 \%$ of the world's conventional petroleum resources. As a result, private companies have increasingly focused on projects located in marginal areas that are often inhabited by indigenous, tribal and minority groups. Drawing on 15 years of experience as advisors to international hydrocarbon companies, we present two case studies involving minority groups in Ecuador and Nigeria. Despite different circumstances, these case studies highlight common challenges faced by social scientists in the oil and gas industry: how to win "broad community support" in places where local leaders may represent only factions, their families or themselves; how to provide real, long-term community benefits; how to resist assuming the role of government despite multiple pressures to do so. Our case studies examine two efforts to address such challenges and provide useful lessons on the limits of corporate social responsibility initiatives.

\section{LICENSE TO OPERATE OR ENERGY GOVERNANCE?}

State-owned national oil companies (NOCs) now control 90\% of the world's conventional oil resources and $75 \%$ of its total production (Tordi, 2011; Frynas, 2011, p. 8). As a result, private companies have increasingly focused on high-risk projects that NOCs cannot undertake without them: exploration and production (E\&P) ventures that require enormous capital outlays, advanced (or proprietary) technology, and extraordinary project management capabilities (Bower, 2009; Yergin, 2011). Many of these projects are located in environmentally difficult, sparsely populated regions - precisely the places that are often inhabited by indigenous, tribal and minority groups. Yet government officials in these countries have generally refused to acknowledge potential claims that indigenous peoples or ethnic minorities might make on land and natural resources, especially valuable hydrocarbons.

Until around 15 years ago, international oil companies (IOCs) were genuinely oblivious to conflicts between minority groups and national governments. Once exploration rights were granted, they tended to focus instead on meeting their contractual obligations (schedule, budget, capital investments) and regulatory requirements (mainly environmental). Getting along with 
local people remained largely an afterthought - and one that often took them by surprise. They generally assumed that access rights to hydrocarbon leases were automatic, and they were taken aback when local people contested their presence.

In the Amazonian countries, however, even the remotest communities generally belong to broader indigenous federations that have demanded a meaningful role in decisions about natural resource development. Many of these federations were formed in the 1960s and 1970s; since the 1980 s, they have allied themselves with international advocacy organizations in a long-term effort to expand the rights of ethnic minorities.

In 1989, they won a major victory when the International Labor Organization adopted Convention 169 Concerning Indigenous and Tribal Peoples in Independent Countries (International Labor Organization 1989). ILO 169 (which was eventually signed by 19 countries) broadened the concept of native land ownership to embrace "the lands they occupy or otherwise use," including traditional hunting and fishing territories - even when national governments claimed that their lands were unoccupied (Article 7). It established the principle that native communities should benefit directly from resource development within such territories. And most essential, it created an obligation for governments to consult with such communities "before undertaking or permitting any programs for the exploration or exploitation of [natural] resources pertaining to their lands" (Article 15).

Thus began an ongoing campaign to enshrine a requirement for "free, prior and informed consent" - the Holy Grail of native rights advocates - in international agreements, development lending, national law and common practice. Major campaign milestones are reflected in World Bank safeguard policies and similar documents (for examples, see World Bank, 1991a; 1991b; International Finance Corporation, 2006 and 2012; United Nations General Assembly, 2007).

In general, IOCs were slow to recognize that such debates might impact their oil and gas exploration activities. They also tended to downplay a simultaneous trend: the "privatization of development" that began in the 1980s (Navarro, 1995): "Business plays an increasingly important role in development. This is linked both to the decline in confidence in the role of the state as an agent for development and to global deregulation from the 1980s...Amid this restructuring key development functions traditionally associated with the state, such as the provision of basic infrastructure and enabling access to water, electricity, health and education, are now performed by a range of civil society and market actors" (Newell and Frynas, 2007, p. 672). Declining government often coincided with the emergence of rent-seeking elites focused primarily on appropriating natural resources. Such trends "deepened into the farming out of core state tasks to non-state entities, the use of remaining levers of the state for the pursuit of private goals, and the abandonment of public goods provision to non-state actors such as NGOs, international organizations, companies or churches" (Soares de Olivera, 2007, p. 86).

As a result, IOCs often found themselves caught between conflicting demands: by government, for greater "social investment" in oil-producing areas; and by minority groups, for greater empowerment and a share in hydrocarbon wealth. To help them navigate these complex issues, they increasingly hired host-country anthropologists, often senior-level academics or development specialists. By the mid-1990s, anthropologists came to occupy the storied role of broker. They managed front-line outreach efforts to ensure what is frequently called the "license to operate" (LTO): active support for company operations from communities and other key nongovernmental stakeholders. They also served as internal advocates, encouraging company managers to push the envelope on transparency and community involvement. 
Meanwhile, they negotiated with those same communities, trying to balance legitimate demands for schools, clinics or sustainable assistance against opportunistic demands for cash or other payments. Their roles generally pass unobserved in most discussions of the oil industry, because they work as staff members or as long-term contractors in overseas E\&P ventures, not in headquarters groups or other relatively visible positions. We exclude anthropologists (generally with bachelor's or master's degrees) employed by environmental consulting firms that prepare social impact assessments, resettlement action plans, and other permit-related documents. Such professionals are only involved in individual projects for short periods (two to four months) and usually play no role in designing "community engagement" initiatives.

In this article, we draw on more than 15 years of experience as advisors to major IOCs in South America and West Africa, particularly the Ecuadorian Oriente (Amazon) and the Niger Delta. While circumstances in Amazonia and Nigeria are vastly different, they also highlight common challenges faced by social scientists who work with oil and gas companies: how to win "broad community support" (in World Bank/IFC parlance) in places where local leaders may represent only factions, their families or themselves; how to provide real, long-term community benefits in regions where government is absent or hostile; how to avoid paternalism or resist assuming the role of government despite multiple pressures to do so. Moreover, most international companies now recognize another disturbing trend: although they have increasingly mastered the task of obtaining LTO, they are largely unable to slow the continued deterioration of civil society around them. Our case studies examine two efforts to address this challenge and provide useful lessons on the limits of corporate social responsibility.

\section{ARCO AND INDIGENOUS PEOPLE IN ECUADOR}

In 1967, oil was discovered in the northeastern Ecuador. Ecuadorian officials saw the impending oil boom as an opportunity to attain one of their most cherished development goals: expanding agricultural production into 5 million hectares of underutilized rainforest. As oil roads extended throughout the region, settlers flooded in and claimed supposedly unoccupied land that included the traditional territory of seven indigenous "nationalities." By 1994, when official colonization ended, nearly one-fifth of the country's Amazonian forests had been cleared and perhaps a dozen oil companies had received exploration rights there.

Settlement in the rainforest brought significant dislocation to native communities: major alterations to traditional economies and social organization, loss of language and disruption of cultural identity. Objections to government policy arose early but were brushed aside. Consider this widely known account of a speech made by President Guillermo Rodríguez Lara in 1972: "On September 25 of that year, the president flew to Puyo in the central Oriente and made a lengthy speech stressing such development objectives as the construction of roads, the provision of public services, and the acceleration of colonization and cash crop production. When a bishop raised the issue that 50,000 Indians lived in the affected areas, Rodríguez Lara maintained that all Ecuadorans were part Indian. 'There is no more Indian problem,' he insisted. 'We all become white men when we accept the goals of the national culture"" (Whitten, Jr., 1976, p. 12). Forced to compete with settlers for legal title to their own lands, indigenous communities joined regional federations to press for greater political inclusion. In 1980, these federations created the

Confederation of Indigenous Nationalities of the Ecuadorian Amazon (CONFENIAE), which remains a powerful force in Ecuador's Indian movement. 
In 1988, the Ecuadorian government awarded petroleum exploration rights in Block 10 to ARCO Oriente, a joint venture involving Petroecuador (the majority shareholder), the operator Atlantic Richfield Corporation (ARCO) and Agip (now part of the Italian company ENI). Block 10 covered 200,000 hectares of relatively pristine Amazonian rainforest in Pastaza Province, south of the country's original oil fields. According to ARCO's country manager, Ecuadorian officials assured the company that Block 10 was unoccupied. In the event, however, it turned out to include more than a dozen well-established indigenous (Quichua-speaking) communities, involving both Catholic and Protestant settlements that were often at odds with each other. Although ARCO had won the right to explore for oil underground, it found that these communities owned the surface land where their equipment would sit.

But negotiations for access to land turned out to be complicated. Catholics and Protestants were represented by separate provincial federations that were soon at loggerheads over dealing with ARCO. Most Catholic communities joined the Organization of Indigenous Peoples of Pastaza (OPIP); most Protestants became members of a rival group, the Association of Protestant Natives of Pastaza, Amazon Region (AIEPRA).

ARCO's exploration efforts did not start off well. In April, 1989, representatives from ARCO and Petroecuador visited a community named Sarayacu, an OPIP stronghold, to negotiate access for seismic crews and other activities. They were detained there until they signed "accords" committing the government to resolve disputed land claims and impose a 15-year moratorium on petroleum activities. The Sarayacu Accords also proposed to create a large "autonomous territory" in Pastaza Province under OPIP's control. One indigenous leader described the agreement as a way of "telling the government that they needed to begin a dialogue with Indian organizations on the country's oil policy and natural resources" (Mendez, et. al., 1998, pp. 1516).

That dialogue never took place. Once its representatives were freed, the government refused to honor the Sarayacu Accords, much less grant territorial autonomy to Pastaza's indigenous organizations. On the contrary, it struck back at OPIP by dividing native land among 19 smaller communal grants. Although many of these "communes" were OPIP members, others remained independent or joined AIEPRA. In his decision against recognizing an "autonomous territory," President Rodrigo Borja denounced OPIP's proposal as a threat to national sovereignty - a position that, with rhetorical modification, has been reaffirmed by every subsequent president of Ecuador, including the current incumbent, Rafael Correa.

Ultimately, ARCO found oil near another village, Villano. Local leaders in Villano decided that their first priority should be to negotiate maximum benefits from the company, rather than pursue OPIP's broader vision of territorial autonomy. "The lack of effective institutions and services in the Villano communities also affected their time horizon. Prior to the services provided by ARCO, the communities had very little in the way of basic health, education, transportation, and communication services. It would have been very difficult for them to hold out and bargain for future, long-term sustainable benefits" (Haley, 2004, p. 202).

In 1993, several villages around Villano withdrew from OPIP and formed their own "Intercommunal Directorate" (later the Association for Indigenous Development, Amazon Region, ASODIRA) to negotiate with ARCO. OPIP and its allies claimed that the company used "divide and conquer tactics" to split the indigenous movement in Pastaza - specifically, to hive ASODIRA off from OPIP (Sawyer, 2004, p. 4; Brysk, 2000, p. 171). But most Villano residents were evangélicos (Protestants) allied with AIEPRA, not OPIP; they profoundly distrusted OPIP 
leaders, whom they accused of pursuing an alien political agenda at their expense (Mendez, et. al.,1998).

Beginning in mid-1995, ARCO realized that it could expect no help or guidance from the government and invited all three local federations to talk. It hired an Ecuadorian development expert (the former regional director of FAO's Forest Trees and Peoples Program office), who had worked with indigenous organizations and enjoyed widespread trust among native communities. Honoring its earlier agreement with OPIP, it convened a "Technical Environmental Committee" (TEC) with representatives from OPIP, AIEPRA and ASODIRA to oversee Villano operations. Over the next three years, TEC members laid out a strategy for environmental monitoring and social investment. At the same time, ARCO and TEC members met directly with community assemblies. These so-called meetings "Good Neighbor Forums" provided an oversight mechanism for community members who often complained that Indian organizations ignored them.

Meanwhile, the government refused to participate in any discussion of its land or energy policies, as Ecuador's indigenous movement demanded. In response, indigenous federations ratcheted up their opposition to oil projects like Villano while demanding broader concessions on Indian territorial and political rights. Together with U.S. and European allies, they launched a campaign against ARCO in the mid-1990s, accusing the company of violating indigenous rights and causing widespread environmental damage.

The Villano campaign was less about ARCO than about a wider conflict within Ecuadorian society: the government's single-minded focus on extracting more oil revenue and OPIP's demand for broader indigenous rights. ARCO persevered in negotiating with all major stakeholders - and in insisting that they negotiate with each other. Eventually, they agreed on a social investment strategy for Villano and surrounding areas. "When all is said and done, Block 10 provided the stage for a series of experiments in building consensus on social and environmental issues arising from deficiencies in Ecuadorian policy. In this context, the sites of consultation that were constructed sui generis throughout the conflict (technical environmental committee and Good Neighbor Forums) should be seen as efforts [by ARCO] to institutionalize relationships with indigenous organizations and communities" (Fontaine, 2004, p. 31). And he cites another lesson learned: broadening the conflict - for example, by bringing in foreign NGOs and launching an international campaign against ARCO - made it harder to find equitable solutions (Fontaine, 2010, p. 21).

\section{OIL DEVELOPMENT AND THE NIGER DELTA}

In Nigeria, relations between oil companies and local communities unfolded within a very different framework. Oil and gas production in the Niger Delta, which began in 1956, has affected thousands of communities across 300 miles of riverine and coastal territory (as well as the "deep offshore"), involving dozens of ethnic groups and subgroups. Unlike Ecuador, Nigeria is a major oil producer and ranks tenth in world oil reserves. Current production levels reportedly hover around 2.2 million barrels/day (bbpd), although installed capacity reaches 2.9 million bbpd (EIA, 2011; Iledare and Suberu, 2010). Nearly 800,000 bbpd (worth around $\$ 60$ million per day) remain "shut in" by sabotage and other disorders or they are lost to bunkering (theft).

According to Nigerian law, oil and gas belong to the Federal Republic of Nigeria. Since 1977, the state-owned enterprise (now named the Nigerian National Petroleum Company, NNPC) has formed joint ventures with foreign operators to find and produce hydrocarbons 
onshore and in shallow coastal waters (Frynas, 1999, pp. 29-34; Ilerare and Seberu, 2010, p. 3). Typically, NNPC holds $60 \%$ of these ventures, which involve five major international operators (Shell, Chevron, ExxonMobil, Total and Agip/ENI). More recently, NNPC has encouraged private companies to explore farther offshore in the Gulf of Guinea, where they are allowed to own deep water production wells outright.

As in Ecuador, the Nigerian government has transferred primary responsibility for social welfare in oil producing areas to foreign oil companies - primarily to Shell and Chevron, the largest onshore operators. But unlike Amazonia, the Delta is not sparely populated: nearly 30 million people are believed to live in the six Delta states where hydrocarbons are usually found. Many of them cluster along remote creeks and or on patches of high ground in swamps that are criss-crossed by flow lines, pumping stations, storage tanks and other oil facilities (see Kashi and Watts, 2008, for stunning photographs of the Niger Delta). They must do without clean water, electricity, jobs, education and health care, while all of these things are available to oil workers.

According to a recent World Bank report, "The divisions between rich and poor are more obvious in the Delta, and declines in the Human Development Index have been steeper for the Niger Delta states than the rest of the Federation. As well, the capital intensive nature of the oil industry means that levels of unemployment and under-employment are higher in the core states of the Niger Delta than in any other region in Nigeria. Furthermore, oil industry-related environmental degradation caused by oil spills, gas flaring and deforestation has undermined opportunities in fishing, agriculture, and related traditional occupations..." (Iledare and Suberu, 2010, p. 13). Most researchers agree that violence has increased after every four-year election cycle as new militant gangs acquire greater firepower (Newsom, 2011, pp. 3-4; Ako, 2011; Boas, 2011). Meanwhile, a small number of powerful Nigerians have become immensely wealthy by appropriating oil rents through "elite capture" of government itself (Soares de Oliveira, 2007). Inevitably, such circumstances have led to escalating violence, as the struggle over federal and state power determines who will be rich and who will not (Human Rights Watch, 2003; 2005; 2008; Leton, 2004).

But elite capture is not the only way that oil money is appropriated. In the early 1990s, gangs of disaffected "youth" often stole oil or equipment and occupied petroleum facilities in their own neighborhoods (Human Rights Watch, 1999, pp. 134-139). They demanded jobs, community projects, training and cash - usually framed as a part of the larger campaign for environmental and social justice. By 1997, they extended their reach to coastal barges and "near off-shore" platforms. Beginning in the early 2000s, however, such events acquired a more ominous cast: "On Independence Day, 1 October 2004, President Obasanjo held talks with Alhaji Musahid Dokubo Asari, the leader of the so-called Niger Delta Volunteer Force, to persuade him to call off Operation Locust Feast, a militia offensive against oil firms. Asari and his associates demanded greater local control of the region's oil and gas resources...Political activists and prodemocracy groups in the Niger Delta have pressed the same demands for many years. Asari and his cohorts differ, however, in that they are linked to organized crime and are armed with relatively sophisticated weapons... Thus behind the reformist rhetoric, the violence in the delta is becoming privatized, interlocking with corruption and electoral politics, including the deployment of militias by state governors to intimidate opponents" (Ibeanu and Luckham, 2007, p. 41).

More recently, Asari's Volunteers have been eclipsed by another group of "conflict entrepreneurs," the Movement for the Emancipation of the Niger Delta (MEND). According to The Economist (2008), MEND "portrays itself as political organisation that wants a greater share 
of Nigeria's oil revenues to go to the impoverished region that sits atop the oil. In fact, it is more of an umbrella organisation for several armed groups, which it sometimes pays in cash or guns to launch attacks." Other researchers offer this description: "It is much less a cohesive force than a brand for large groups of insurgents, militias and gangs, and owing to its networked and fragmented nature also very hard to crush..." (Boas, 2011, p. 121). In this respect, Nigeria has come to resemble Colombia, where until various guerrilla and paramilitary franchises controlled large territories, financed themselves with drug sales and kidnapping for ransom, and bought kidnap victims from non-political thugs, while maintaining a rhetoric of social reform. By 2005, Nigerians themselves were drawing similar analogies. In short, "the lines between militancy and criminality have become blurred" (Obi and Rustad, 2011, p. 3).

Of course, legitimate political protest - most notably, the Movement for the Survival of the Ogoni People (MOSOP) - has sought political and social space in the Niger Delta (Human Rights Watch, 1999; Ibeanu and Luckham, 2007, pp. 65-68). But even these groups often cannot escape the vortex of perverse incentives. A detailed chronology of resource conflicts in Nigeria concludes with the observation that "the movements themselves have become corrupted by the political economy of oil. Demonstrations, takeovers of oil installations, attacks on pumping stations and pipelines, and kidnappings of foreign and Nigerian oil workers have increasingly been used by 'youths', community 'big men', political entrepreneurs and armed criminal gangs to extract their own shares of resource rents. They have also become increasingly violent, pitting communities against each other, as well as opening deep rifts within them" (Ibeanu and Luckham, 2007, pp. 64-65). And finally, often-repeated arguments that blame violence on inadequate social investment miss the mark and ignore the vast sums that have been spent on development. As one researcher has suggested, the issue is not money but disempowerment - the lack of "genuine direct engagement with beneficiary communities as agents in the planning and implementation of development initiatives" (Ahonsi, 2011, p. 39).

\section{THE GMOUs: COMMUNITY FOUNDATIONS IN THE NIGER DELTA}

Until 2005, international companies in the Niger Delta generally followed familiar patterns in dealing with surrounding communities. They bargained with traditional leaders over low-level jobs for "youth" (men up to around 35 years old); boreholes and other small infrastructure projects; new school buildings with the company's logo prominently displayed; scholarships (often appropriated by local chiefs); and so-called "homage payments." In return, the chiefs guaranteed access to pipelines, pumping stations or other equipment. Generally speaking, this approach divided communities into "haves" and "have nots" based on proximity to company property, ethnic affiliation or other differences.

Inequalities of this sort became particularly dangerous when "host community" boundaries also coincided with ethnic boundaries, as they did near Chevron's main onshore oil terminal at Escravos. Throughout the 1990s, for example, CNL spent \$28 million on schools, hospitals and other community benefits (Human Rights Watch 1999, p. 104). Yet violence against Chevron Nigeria Ltd. (CNL) and other companies rose sharply over the same years; in particular, interethnic conflict between Ijaw and Itsekiri villages often wreaked havoc on local settlements (Human Rights Watch, 2003; Leton, 2006; Courson, 2007; International Crisis Group, 2006a; 2006b).

Such conflicts arose from multiple sources but were "always locally rooted, reflecting the particular historical configuration of customary forms of rule and governance, company activity, 
the history of inter-ethnic relations, and local government and state forces" (Watts, Okonta and Van Kemedi, 2005, p. 3). Hospitals were burned, schools and water pumps were abandoned, fish farms were plundered. To make matters worse, an "entitlement mentality" - rent seeking at the village level - had also taken hold (Frynas, 2009, p. 125). Offered training in construction trades or other jobs, for example, local people frequently rejected it. "It's our oil," they argued, "We should be paid for it." In 1999, CNL decided to radically refocus its efforts away from traditional LTO strategies and focus instead on addressing the root causes of conflict.

CNL's new approach shifted decision-making about social investment from the company's own representatives to local communities and ethnic groups. With technical assistance from Niger Delta-based NGOs, community members assessed their own needs, evaluates potential trade-offs (e.g., a new chief's palace vs. potable water), and selected high-priority projects. For want of a better term, this approach was called the "Global Memorandum of Understanding" (GMOU).

By late 2005, Chevron had set up eight Regional Development Councils (community foundations) throughout its operating area and recruited nearly 30 NGOs to support them. All RDCs signed virtually the same agreement: in return for identifying and implementing projects with the greatest benefit for local people, they received an annual allocation from Chevron based on their population and the value of CNL's assets or oil production within area. The company also persuaded state governments to pay a share of RDC activities from their so-called "derivation funds" (at the time, 13\% of Nigeria's hydrocarbon revenues). And it abandoned the notion of "host community" - a source of endless friction - in favor of more inclusive social and cultural boundaries.

Of course, the challenges were daunting. In most areas, autocratic local rule was the norm. How to ensure that RDCs were, in fact, representative - in particular, that community members, not just elites, would have a real voice? Without strict financial and other controls, the potential for corruption and mismanagement was overwhelming. What additional safeguards would be put in place? And the biggest challenge of all: for the first time in 20 years CNL would not be responsible for the success or failure of every project. If something went wrong, RDCs, not Chevron, would be held to account. Finally, the GMOUs realigned previous incentives: bonus payments were offered for maintaining peace, but these bonuses were withheld when violence or destruction occurred. Thus Chevron hoped that RDCs would find innovative ways to restrain "conflict entrepreneurs" who benefited most from endemic disorder.

But where to start? Here CNL took another bold step: it invited highly qualified Nigerian experts, rather than its own staff members, to manage the GMOUs. It engaged a respected nonprofit organization, Enterprise for Development International, as its strategic partner, with additional support from the New Nigeria Foundation. Together with CNL's external advisors (Terra Group), these experts then adapted a British participatory needs assessment tool known as "sustainable livelihoods assessment" (SLA) for use by RDCs and Delta communities. SLAs served a dual purpose. They provided baseline social and economic information for three-year community investment plans, which RDCs were required to prepare before receiving their annual budget from Chevron. More important, they helped local people, who were often separated by conflicting allegiances and interests, to reach consensus about local priorities.

Eventually, 32 SLAs were completed in 450 communities over 18 months. Research findings were validated and revalidated in community meetings to ensure that they represented consensus understandings. And in what may have been another milestone, women were actively included as SLA participants. (Although they are often the sole providers of household income, most Delta 
women remain marginalized and have little voice in local affairs.) The SLAs provided a disturbing but realistic glimpse of conditions in Chevron's operating area:

- Household sizes ranged from 12 to 17 people (households generally defined as "all who eat from the same pot").

- Nearly $75 \%$ of households depended on fishing or casual labor and many households faced seasonal food shortages or starvation. Even in good times, most people did not eat three meals a day.

- Polygamy was rising in remote areas because younger men usually left their villages to seek work elsewhere. Young women were often forced to marry older men who already had three, four or five wives. Several SLA researchers equated their situation with domestic slavery.

- Children numbered more than $50 \%$ of the population in each village, but only a handful attended school.

- A vast majority of adults were illiterate and had never been to school.

- Although Chevron and Shell had been providing infrastructure for 20 years, most of it was missing or non-functional. Among 425 communities, only 27 schools were in full use, and only 19 electric generators could be found. Meanwhile, researchers counted 15 boreholes, wells or pipes out of dozens that had been constructed. Only one health clinic operated among coastal communities; and no health facilities at all existed in the swamps.

Based on these data, the RDCs emphasized water and sanitation as their first priority, followed by renovating dilapidated schools and clinics, improving health and education and strengthening local businesses. The emphasis on renovation was especially encouraging: in the past, communities simply insisted that Chevron or Shell build new facilities, which quickly fell into disrepair. In contrast, the RDCs hired local people to restore existing "assets" and then lobbied state and federal agencies to provide the requisite teachers, health workers, materials, etc.

Of course, the GMOUs are not magic and cannot erase three generations of mis-development overnight. Deep fissures within civil society remain and will not be easily bridged. In 2008, Chevron commissioned an independent evaluation of its progress and found several serious gaps (Research Triangle Institute, Search for Common Ground and Consensus Building Institute, 2008):

- Coordination with government was "minimal and inadequate."

- "Many [communities] still expect the handouts and benefits of the previous system, causing tensions."

- "Funding levels are inadequate to address the extensive needs of communities."

Disturbingly, the evaluators also noted that "communication between the RDCs and communities they represent is very poor. RDCs are not using the GMOUs' built-in communication mechanisms." As a result, women and youth continued to report that they are excluded from RDC decision-making. Another obvious weakness: no one "systematically measures the effectiveness of its development interventions, either in terms of scientific measures (e.g., changes in health indicators related to health spending) or in terms of a value-formoney analysis" (Frynas, 2009, p. 110). One critic has also argued that GMOUs are controlled by "a somewhat opaque set of committees," which circumvent community development councils 
and other local institutions (Zalik, 2011a., pp. 190-191; see also Zalik, 2011b; Idemudia, 2011). As a result, they "change the way the population has laid claim to the natural resource base" creating an updated version of "host communities" with their arbitrary winners and losers. Yet despite its shortcomings, the GMOU approach seems to be working (Onuhoa, 2011).

Since 2005, CNL has provided more than $\$ 56.7$ million to RDCs for community-level projects in around 400 communities. Such projects include clean water, electricity and health care for poor communities that until now have received nothing from Nigeria's oil wealth. The GMOU agreements themselves are due to be renewed for the third time, with continuing steps toward greater inclusiveness and transparency. Violence throughout the region has dropped significantly.

\section{CONCLUSIONS: BEYOND LTO}

These case studies highlight essential lessons for international corporations operating in weak, conflict-prone states around the world. After following a conventional LTO approach, ARCO and Chevron recognized that simply providing "fair and just" compensation to local landowners (including communities) would not address the underlying sources of conflict: poverty, disempowerment and discrimination. They eventually improvised new "sites of consultation" (in Fontaine's words) as an alternative to failed and undemocratic government: the Technical Environmental Commission and Good Neighbor Forums in Ecuador; RDCs and SLAs in Nigeria.

Within such spaces, companies, communities and other stakeholders have conducted "a series of experiments" to broaden participatory practice and decision-making. In particular, the GMOUs are aimed at overcoming two of the main weaknesses found in most corporate social responsibility initiatives: "a key constraint to CSR's role in development is the business case, that is, the subservience of any CSR schemes to corporate objectives...profit-maximizing motives are often incompatible with good development practice. Given that oil companies are not development agencies, they do not tend to prioritize overall development goals, and there are inherent limitations to how corporate social initiatives can address the concerns of local communities" (Frynas, 2009, pp. 131-132). Yet both the GMOUs and the Technical Committee in Ecuador demonstrate that oil companies are capable of moving beyond "the tendency to use CSR more as a business tool than a development tool" (Idemundia, 2011, p. 176).

The problem comes in institutionalizing such experiments. Eventually, they are almost certain to collide with the "boundary conditions" set by governing elites - just as the World Bank's oil revenue management plan collapsed in Chad when it became inconvenient for the country's president. "Even the most enlightened and far-reaching CSR initiatives may face systemic constraints arising from the existing systems of societal governance... a shift in focus from micro-level CSR activities towards macro-level governance issues is crucial in addressing development issues" (Frynas, 2009, p. 138).

What would this "shift towards macro-level governance issues" look like? For now, major human rights organizations and their allies have focused primarily on raising the "consent standard" in international treaties and World Bank/IFC guidelines. By requiring international companies to obtain "free, prior and informed consent" from indigenous and minority communities, for example, they argue that FPIC represents "an important and fundamental tool to ensure that indigenous peoples will benefit from the resources within their ancestral territory" (Mayo-Anda, et. al., 2006, p.1). Along the same lines, advocacy groups also suggest that 
expanded community participation in resource extraction projects will provide a "valuable risk management tool" and will produce fairer, more sustainable outcomes (Herbertson, et. al., 2009). Yet our case studies suggest that these arguments may be overly simplistic and ignore essential facts on the ground. Despite their best intentions, we would argue that they reinforce a pernicious and dysfunctional status quo: the privatization of government responsibility for social welfare, FPIC and other obligations. As the United Nations Human Rights Council has recently recognized $(2008 ; 2011)$, it is governments that have the obligation to protect human rights and make equitable decisions about natural resources; companies must respect these rights and deal fairly with their neighbors.

Nonetheless, foreign oil and gas companies can lead by example. Chevron's GMOUs have been copied by other companies and have spread throughout the Niger Delta (although with considerable criticism; see Odi and Rustad, 2001). State governments, heretofore virtually inaccessible and unaccountable to local people, sit at the table with RDCs and non-profit development groups. Like the Technical Environmental Committee and Good Neighbor Forums in Ecuador, GMOUs have provided an experience of meaningful participation, greater involvement of women and minorities, and relatively transparent decision-making in marginalized and disempowered communities. They represent a first meaningful step toward "the identification and mobilization of community associations such as youth groups and neighborhood councils...women's cooperatives and local faith-based organizations" to play a key role in their own development (Ahonsi, 2011, p. 40). As anthropologists, we can help companies understand these challenges and design more effective strategies to address them. At the same time, we must be realistic about what such measures can achieve. Business can be a powerful agent for social change and should be encouraged to take innovative steps. Yet it should not be tasked with responsibilities that it cannot perform well or that belong elsewhere. Even the best corporate social performance is unlikely to solve the problem of bad governance in Africa or Latin America. Still, it provides one essential piece of the solution.

\section{REFERENCES}

Ahonsi, B. (2011). Capacity and governance deficits in the response to the Niger Delta Crisis. In Obi, C. \& Aas Rustad, S. (Eds.), Oil and Insurgency in the Niger Delta (pp. 28-42), London: Zed Books.

Ako, R. (2011). The struggle for resource control and violence in the Niger Delta. In Obi, C. \& Aas Rustad, S. (Eds.), Oil and Insurgency in the Niger Delta (pp. 42-54). London: Zed Books.

Boas, M. (2011). 'Mend Me': the Movement for the Emancipation of the Niger Delta and the empowerment of violence. In Obi, C. \& Aas Rustad, S. (Eds.), Oil and Insurgency in the Niger Delta (pp. 115-124). London: Zed Books.

Bower, T. (2009). Oil. Money, Politics, and Power in the $21^{\text {st }}$ Century. New York: Grand Central Publishing.

Brysk, A. (2000). From Tribal Village to Global Village: Indian Rights and International Relations in Latin America. Stanford: Stanford University Press. 
Courson, E. (2007). The Burden of Oil. Social Deprivation and Political Militancy in Gbaramatu Clan, Warri South West LGA, Delta State, Nigeria (Working Paper 15). Retrieved from University of California, Berkeley, Institute of International Studies website:

http://oldweb.geog.berkeley.edu/ProjectsResources/ND\%20Website/NigerDelta/WP/15Courson.pdf

Fontaine, G. (2004). Análisis y evaluación de la gestión de los conflictos en el Bloque 10 (Ecuador). Quito: Facultad Latinoamericana de Ciencias Sociales.

Fontaine, G. (2010). Parapolítica. Una teoría de la gobernanza energética. Quito: Facultad Latinoamericana de Ciencias Sociales.

Frynas, J. G. (1999). Oil in Nigeria. Conflict and Litigation between Oil Companies and Village Communities. London: LIT Verlag.

Frynas, J. G. (2009). Beyond Corporate Social Responsibility. Oil Multinationals and Social Challenges. New York: Cambridge University Press.

Haley, S. (2004). Institutional Assets for Negotiating the Terms of Development: Indigenous Collective Action and Oil in Ecuador and Alaska. Economic Development and Cultural Change, 53, 191-213.

Herbertson, K., Ballesteros, A., Goodland, R. \& Munilla, I. (2009). Breaking Ground. Engaging Communities in Extractive and Infrastructure Projects. Washington: World Resources Institute.

Human Rights Watch. (1999). The Price of Oil. Corporate Responsibility and Human Rights Violations in Nigeria's Oil Producing Communities. New York: Human Rights Watch.

Human Rights Watch. (2003). The Warri Crisis: Fueling Violence. HRW Report (Volume 15, No. 18 (A), December). Retrieved from HRW website:

http://www.hrw.org/reports/2003/12/17/warri-crisis-fueling-violence-0

Human Rights Watch. (2005). Rivers and Blood: Guns, Oil and Power in Nigeria's Rivers State. Washington: HRW. Retrieved from HRW website:

www.hrw.org/legacy/backgrounder/africa.nigeria0205.pdf

Human Rights Watch. (2008). Politics as War. The Human Rights Impact and Causes of PostElection Violence in Rivers State, Nigeria. Washington: HRW. Retrieved from HRW website: http://www.hrw.org/sites/default/files/reports/nigeria0308webwcover.pdf

Ibeanu, O. \& Luckham, R. (2007). Nigeria: political violence, governance and corporate responsibility in a petro-state. In Kaldor, M., Karl, T. \& Said, Y. (Eds.), Oil Wars (pp. 41-99). London: Pluto Press. 
Idemudia, U. (2011). Corporate social responsibility and the Niger Delta conflict: issues and prospects. In Obi, C. \& Aas Rustad, S. (Eds.), Oil and Insurgency in the Niger Delta (pp. 167183). London: Zed Books.

Iledare, W. \& Suberu, R. (2010, March). Oil and Gas Resources in the Federal Republic of Nigeria. Paper presented at the meeting of the World Bank and the Forum of Federations, Washington D.C. Retrieved from website:

http://siteresources.worldbank.org/EXTOGMC/Resources/336929-

1266445624608/Nigeria_Conference_Finaldraft_Feb10.pdf

International Crisis Group. (2006a). Fueling the Niger Delta Crisis (Africa Report 118). Brussels: International Crisis Group. Retrieved from ICG website:

http://www.liberationafrique.org/IMG/pdf/118_fuelling_the_niger_delta_crisis.pdf

International Crisis Group. (2006b). The Swamps of Insurgency: Nigeria's Delta Unrest (Africa Report 115). Brussels: International Crisis Group. Retrieved from ICG website:

http://www.crisisgroup.org/ /media/Files/africa/west-

africa/nigeria/The $\% 20$ Swamps $\% 20$ of $\% 20$ Insurgency $\% 20$ Nigerias\%20Delta $\% 20$ Unrest.pdf

International Finance Corporation. (2006; revised in 2012). "Policy on Social and Environmental Sustainability." Retrieved from IFC website:

http://www.ifc.org/ifcext/policyreview.nsf/AttachmentsByTitle/Updated_IFC_SFCompounded_ August1-2011/\$FILE/Updated_IFC_SustainabilityFrameworkCompounded_August1-2011.pdf

Kashi, E. \& Watts, M. (2008). Curse of the Black Gold. Brooklyn: PowerHouse Books.

Korovkin, T. (2003). In Search of Dialogue: Oil Companies and Indigenous Peoples in the Ecuadorian Amazon. Canadian Journal of Development Studies, 23, 632-663.

Leton, M. (2006). Oil and the Urban Question. Fuelling Violence and Politics in Warri. (Working Paper No. 8). Retrieved from University of California, Berkeley, Institute of International Studies website:

http://oldweb.geog.berkeley.edu/ProjectsResources/ND\%20Website/NigerDelta/WP/8-Leton.pdf

Mayo-Anda, G., Cagatulla, L.\& La Viña, A. (2006). Is the Concept of "Free and Prior Informed Consent" Effective as a Legal and Governance Tool to Ensure Equity Among Indigenous Peoples? Bohol, Philippines: Environmental Legal Assistance Center, Inc. Retrieved from Indiana University website:

http://dlc.dlib.indiana.edu/dlc/bitstream/handle/10535/2204/Mayo_Anda_Grizelda_Cagatulla_La _Vina.pdf? sequence $=1$

Mendez, S., Parnell, J. \& Wasserstrom, R. (1998). Seeking Common Ground. Petroleum and Indigenous Peoples in Ecuador's Amazon. Environment, 40, 12-45. 
Navarro, M. (1995). Conflictos en políticas de asignación y uso de los Fondos de Beneficio Social y Mitigación de Impacto Ambiental de las Petroleras. In Varea, A. \& Ortíz P. (Eds.), Marea negra en la Amazonía (pp. 181-218). Quito: Ediciones Abya Yala.

Newell, P. \& Frynas, J. G. (2007). Beyond CSR? Business, poverty and social justice: an introduction. Third World Development, 28, 669-681.

Newson, C. (2011,). Conflict in the Niger Delta. More than a Local Affair (Special Report 271, June). Washington: United States Institute of Peace.

Nigeria. Risky toughness. The army's tough approach to Delta militants could end up uniting them. (2008). The Economist, September 18. Retrieved from http://www.economist.com/node/12267373?story_id=12267373

Obi, C., \& Aas Rustad, S. (2011). Introduction: Petro-violence in the Niger Delta - the complex politics of an insurgency. In Obi, C. \& Aas Rustad, S. (Eds.), Oil and Insurgency in the Niger Delta (pp. 1-16). London: Zed Books.

Onuhoa, A. (2011). Chevron's GMOU: A Strategy for Sustainable Community Empowerment. In Schilling, D. (Ed.), Building Sustainable Communities through Multi-Party Collaboration. New York: Interfaith Center on Corporate Responsibility. Retrieved from ICCR website: http://www.iccr.org/publications/2011SSRG.pdf

Research Triangle Institute (RTI), Search for Common Ground and Consensus Building Institute. (2008). GMOU Participatory Stakeholder Evaluation: A Joint Evaluation of the Global Memoranda of Understanding between Chevron, Community Organizations and State Governments in the Niger Delta. Retrieved from RTI website: $\mathrm{http} / /$ cbuilding.org./sites/default/files/GMOU_Evaluation_Final.pdf .

Sawyer, S. (2004). Crude Chronicles. Durham: Duke University Press.

Soares de Oliveira, M. (2007). Oil and Politics in the Gulf of Guinea. New York: Columbia University Press.

Tordo, S. (2011). National Oil Companies and Value Creation. Washington: World Bank. Retrieved from World Bank website:

http://siteresources.worldbank.org/INTOGMC/Resources/noc.pdf

United Nations General Assembly. (2007). Declaration on the Rights of Indigenous Peoples. Retrieved from UN website: http://www.un.org/esa/socdev/unpfii/en/drip.html

United Nations Human Rights Council. (2008). Promotion and Protection of All Human Rights, Civil, Political, Economic, Social and Cultural Rights, Including the Right to Development. Protect, Respect and Remedy: a Framework for Business and Human Rights. Retrieved from UN website: 
http://www.unglobalcompact.org/docs/issues_doc/human_rights/Human_Rights_Working_Grou p/29Apr08_7_Report_of_SRSG_to_HRC.pdf

United Nations Human Rights Council. (2011). Final Report of the Special Representative of the Secretary-General on the issue of human rights and transnational corporations and other business enterprises, John Ruggie. Retrieved from UN website: http://www.businesshumanrights.org/media/documents/ruggie/ruggie-guiding-principles-21-mar-2011.pdf

U.S. Department of Energy. Energy Information Administration. (2011). Country Analysis Briefs. Nigeria. Retrieved from Department of Energy website:

www.eia.gov/countries/cab.cfm?fips=NI

Watts, M., Okonta, I., \& Van Kemedi, D. (2004). Economies of Violence. Petroleum, Politics and Community Conflict in the Niger Delta, Nigeria (Working Paper No. 1) Retrieved from University of California, Berkeley, Institute of International Studies website:

http://oldweb.geog.berkeley.edu/ProjectsResources/ND\%20Website/NigerDelta/WP/1WattsOkantaVon.pdf

Whitten, N., Jr. (1976). Ecuadorian Ethnocide and Indigenous Ethnogenesis: Amazonian Resurgence Amidst Andean Colonialism (IWGIA Document 23). Copenhagen: International Work Group on Indigenous Affairs.

World Bank. (1991a). Operational Directive 4.20, "Indigenous Peoples.” (Reissued as Operational Procedure 4.10, 2005). Retrieved from World Bank website: http://web.worldbank.org/WBSITE/EXTERNAL/PROJECTS/EXTPOLICIES/EXTOPMANUA L/0, contentMDK:20553653 menuPK:4564185 pagePK:64709096 piPK:64709108 theSitePK: 502184,00.html

World Bank. (1991b). Operational Directive 4.30, "Involuntary Resettlement" (Revised and reissued as Operational Procedure 4.12, 2001 and 2011). Retrieved from World Bank website: http://web.worldbank.org/WBSITE/EXTERNAL/PROJECTS/EXTPOLICIES/EXTOPMANUA $\mathrm{L} / 0$, contentMDK

Yergin, D. (2011). The Quest. Energy, Security, and the Remaking of the Modern World. New York: Penguin Press.

Zalik, A. (2011a). Labelling oil, contesting governance: Legaloil.com, the GMoU and profiteering in the Niger Delta. In Obi, C. \& Aas Rustad, S. (Eds.), In Oil and Insurgency in the Niger Delta (pp. 184-199). London: Zed Books.

Zalik, A. (2011b). Protest as Violence in Oilfields: The Contested Representation of Profiteering in Two Extractive Sites. In Feldman, S., Geisler, C., \& Menon, G. (Eds.), Accumulating Insecurity, (pp. 61-28). Athens, University of Georgia Press. 